\title{
Dissection of Mammalian Organs and Opinions about It among Lower and Upper Secondary School Students
}

ANDREJA ŠPERNJAK ${ }^{* 1}$ AND ANDREJ ŠORGO ${ }^{2}$

$\approx$ This article describes the results of a study that investigated the use of the dissection of organs in anatomy and physiology classes in Slovenian lower and upper secondary schools. Based on a sample of 485 questionnaires collected from Slovenian lower and upper secondary school students, we can conclude that dissection of mammalian organs during the courses on Human Anatomy would be a preferred activity for the majority of them. Opinions on such practices are positive, and only a minority of students would prefer to opt out. However, the practice is performed only occasionally in regular classes, or even omitted, and a number of students never participate in it. According to the results, we can suggest the dissection of mammalian organs in combination with alternatives, such as $3 \mathrm{D}$ models and virtual laboratories, as a preferred strategy to increase knowledge of anatomy and to raise interest in science. However, students should know that the organs they are dissecting were dedicated to human consumption, or are waste products in these processes. Opt-out options should be provided for those who do not want to participate in such activities.

Keywords: biology laboratory work; dissection; interest in dissection; lower secondary students; upper secondary students

$1{ }^{*}$ Corresponding Author. University of Maribor, Faculty of Natural Sciences and Mathematics, Slovenia; andreja.spernjak@uni-mb.si.

2 University of Maribor, Faculty of Natural Sciences and Mathematics, Slovenia. 


\section{Seciranje organov sesalcev v osnovi in srednji šoli ter njihovo mnenje o sekciji v razredu}

ANDREJA ŠPERNJAK IN ANDREJ ŠORgO

$\approx$ V članku so predstavljeni izsledki raziskave o sekciji organov pri urah anatomije in fiziologije človeka $\mathrm{v}$ osnovnih in srednjih šolah. $\mathrm{V}$ študijo je bilo vključenih 485 učencev in dijakov iz različnih osnovnih in srednji šol. Iz rezultatov lahko sklepamo, da si večina vprašanih pri urah biologije želi več sekcije organov. Učenci in dijaki $\mathrm{v}$ večini podpirajo izvedbo sekcije organov in le majhen odstotek vprašanih sekcije med izobraževanjem ne želi izvajati. Glede na rezultate vprašanih sklepamo, da je sekcija organov $v$ slovenskih šolah redka praksa ali pa je med šolanjem sploh ne izvajajo in je popolnoma izpuščena. Ker si večina vprašanih pri urah biologije želi sekcije organov sesalcev kot prednostno strategijo za dvig znanja o anatomiji sesalcev in povečanje zanimanja za naravoslovje, predlagamo izvedbo sekcije $\mathrm{v}$ kombinaciji $\mathrm{z}$ rabo drugih učnih pripomočkov, kot so $3 \mathrm{D}$-modeli organov ali virtualni laboratoriji. Pri sekciji organov je učence in dijake treba seznaniti, da so bili organi za sekcijo namenjeni za prehrano ljudi ali pa so kot odpadni produkt v procesih predelave hrane. Za učence in dijake, ki pri sekciji ne želijo sodelovati, je treba zagotoviti možnost izbora in pripraviti druge dejavnosti.

Ključne besede: biološko laboratorijsko delo, interes za seciranje, osnovnošolci, seciranje, srednješolci 


\section{Introduction}

Biology is a discipline about living beings, and there is no scientific evidence about the presence of life outside organisms. Study of the interiors of 'homes of life' is a part of the standard content of biology courses/subjects at the primary and secondary educational levels and is regarded as essential for biology, veterinary and medical students (Macchi, Porzionato, Stecco \& Caro, 2014) at the tertiary levels. In formal education, different instructional methods exist to attain knowledge and experience about the internal anatomy of animals and humans. Methods range from expository instructions, as verbal and multimedia presentations, exposition of models and fresh or conserved animals by teachers or teaching assistants, to the first-hand experiences of students as dissection in biology/anatomy classrooms, and in recent times as interactive virtual dissections (Saltarelli, Roseth \& Saltarelli, 2014) and use of ${ }_{3} \mathrm{D}$ printed models (Fancovicova \& Prokop, 2014; Fredieu, Kerbo, Herron, Klatte \& Cooke, 2015; McMenamin, Quayle, McHenry \& Adams, 2014). All instructional methods used in anatomy teaching, except dissection itself, have in common that they can be recognised as derivatives of dissection, because there is no alternative to obtaining primary insight inside the bodies of members of the animal kingdom.

Globally, differences between countries in the views and position on dissection exists, largely based on the dominant teaching culture and values of a society, with trends for the exclusion of animal dissection or its replacement by virtual alternatives (Demirhan, 2014; Osenkowski, Green, Tjaden \& Cunniff, 2015). For instance, in the USA, the National Science Teachers Association (NSTA, 2005) supports the decision of science teachers to integrate live animals and dissection into the classroom. However, regardless of the support of NSTA authorities, the dissection of a whole animal or organ is a common practice only in some school districts' biology curricula and absent in others (Mattheis, Ingram, Jensen \& Jackson, 2015). Schools in five countries (Argentina, Israel, the Netherlands, Slovakia, and Switzerland) do not conduct dissections, and the practice is rare or being phased out in other countries, including England, Sweden, and India (Oakley, 2011). In German biology classes, dissections are required by educational authorities, e.g. by the Ministry of Culture and Education in Lower Saxony (Holstermann, Grube \& Bögeholz, 2009). At semi-formal levels, dissection is an obligatory activity of the practical part of International Biology Olympiads (A Guide to the International Biology Olympiad, 2015). In Slovenian schools, dissection of mammalian organs is encouraged by national documents on biology/science education but in practice entirely depends on 
the teacher's autonomous decision and discretion to include it in teaching or not. To our best knowledge, studies about the status of dissection in Slovenian schools do not exist, which was one of the main incentives to begin our research.

The dissection of organs as a part of biology laboratory work has been recognised as beneficial with arguments that dissection can help students to develop skills of observation and comparison, discover the shared and unique structures of specific organisms, and develop a greater appreciation for the complexity of life (NSTA, 2005). However, some authors have claimed that animal dissection is a controversial pedagogical practice. In educational contexts, it raises ethical and environmental concerns regarding the killing of animals, the ignoring of animal welfare standards, the weakening of respect for life, and the 'turn-off' factor for some students (Balcombe, 2000; Bishop \& Nolen, 2001; Hug, 2008; Jukes \& Chiuia, 2003; Marr, 2001; Oakley, 2009; Sapontzis, 1995). As Balcombe (2000) writes, there is an ethical question underlying the justification of killing animals to learn how they work, even if this is thought to be the best way to teach.

In Slovenian schools, teachers are allowed to dissect mammalian organs that have been obtained in a slaughterhouse or butcher shop unless they contain bovine nervous tissues, due to possible BSE transfer. The same is true for other vertebrates, which leaves only the dissection of birds (poultry) and fish. However, the raising of vertebrates as model organisms in a school vivarium is encouraged, but not with the purpose of dissection. Practices of whole body mammalian dissection. such as dissection of rodents has been abandoned in elementary and secondary schools. By using animals or their parts for human consumption, ethical questions are largely reduced, because all dissections in schools are performed on organs or animals for which dissection was not the sole or primary purpose of killing the animal. However, due to different reasons, some students would prefer to opt out of dissection. Since dissection can negatively impact students' self-efficacy beliefs and interest levels, adolescents are not pressured to perform dissection or have contact with dead organs (Holsterman et al., 2009). Based on conversations with teachers, which were part of regular visits to schools by the authors of the present paper, the most common practice is that students are allowed to opt out of dissection without penalty. However, due to school regulations, they are not allowed to leave the classroom: in the most cases, they observe dissection from a distance, following the socalled opt-out scheme (Cunningham, 200o).

Because of ethical concerns about dissection, alternatives have been sought, recently in virtual worlds (Peat \& Taylor, 2005). Research based on all educational levels indicates that outcomes pertaining to learning anatomy and 
physiology can be met by virtual alternatives, and that students' gained knowledge can be equivalent, and sometimes superior, to traditional dissections (Cottam, 1999; Lalley, Piotrowski, Battaglia, Brophy \& Chugh, 2010; Maloney, 2005). In contrast, Kerby, Shukur, and Shalhoub (2011) claimed that while the use of computer simulations and virtual dissection serve as valuable teaching tools, they simply cannot replace hands-on experience that dissection affords. In a review of studies designed to compare the effectiveness of various forms of instruction for first-year medical students, Winkelmann (2007) found that the literature suggests advantages of traditional hands-on dissection, but does not discount the value of alternative methods, including prosection and the use of computerised multimedia imaging programs. Many medical educators view dissection as a learning experience that cannot be replicated through other means. De Villiers and Monk's (2005) review of research on the topic not only revealed ongoing tensions within the field, but also acknowledged the fact that strong support remains for this type of hands-on learning of anatomy despite the increased availability of alternative and virtual experiences. Additionally, as noted by Richardson (2011), even the best virtual dissection activities have inherent contradictions to the fundamental nature of anatomy, physiology, and science in general, as they do not entirely effectively convey the distinction between living organisms and machines and the unpredictability of living organisms and systems. Richardson (2011) warned that virtual dissections may promote misconceptions and lead to overgeneralisation. Most probably, the best learning outcomes are achieved by a combination of real and virtual dissection not as exclusive but as complementary. A body of research shows that a combination of real and virtual, both as used virtual for preparation for virtual dissection or used for confirmation and repetition outperformed using each technique separately (Akpan \& Andre, 2000; Akpan, 2002; Smetana \& Bell, 2012).

The dissection of human organs is out of scope in Slovenian secondary schools and challenged at university levels. Because linking the structure of organs with function is considered to be a basic science concept, dissections of pig or cow organs are set in the context of human biology in order to illustrate how human organs are built and work (Entrich, 1996; Mattheis, Ingram, Jensen \& Jackson, 2014).

\section{Research questions and aim of the study}

In Slovenian schools, the dissection of mammalian organs is recommended but, to our best effort, we were not able to find a study about the actual use of dissection in schools or on interest and attitudes toward this practice 
among students. This paper intends to contribute to this issue.

Our research questions were as follows:

- Which mammalian organs, if any, do students dissect during their biology laboratory work?

- Which mammalian organs would they prefer to dissect, if any?

- Would participants show more interest in the dissection of organs if they had such experiences from biology/science classes?

- $\quad$ Are there any differences in opinion between participants on the dissection of organs regarding school level and gender?

\section{Methods}

\section{Sample and sampling}

Our study is exploratory by design, and no interventions were made in classroom practice. The participants for this study were students of six different lower secondary (Level 2 by ISCED, 2011) and six different upper secondary schools (Level 3, ISCED, 2011) from Slovenia. Interested readers can obtain more information on the Slovenian school system from international webpages, e.g. http://www.ukom.gov.si/en/media_room/background_information/education/ educational_system_in_slovenia/.

Prior to the survey, permission was obtained from the school authorities. Participants were asked to complete a questionnaire in paper-and-pencil format prepared for the purpose of the study during their regular classes, following the standard protocol. During the initial phase, they were informed about the goals of the research, given specific instructions about filling the questionnaire fields, and guaranteed anonymity. Additionally, they were informed that answering was on a free will basis, so anybody could opt out anonymously by simply returning an unanswered questionnaire at the end of the session, and that no benefits were provided. There were no specific time constraints, but respondents typically needed about 10 minutes to complete the survey. We collected 483 questionnaires. The students were aged between 14 and 18 years old; 280 students were from the $8^{\text {th }}$ grade (179 students; $\left.37.1 \%\right)$ and $9^{\text {th }}$ grade (101 students; 20.9\%). From seven high schools, 203 questionnaires were collected (44 students $(9.1 \%)$ from $1^{\text {st }}$ year, 22 students $(4.6 \%)$ from $2^{\text {nd }}$ year, and 137 students $(28.4 \%)$ from $3^{\text {rd }}$ year). We collected 207 questionnaires from boys $(42.9 \%)$ and 276 questionnaires from girls $(57 \cdot 1 \%)$. 


\section{Structure of the survey instrument}

The questionnaire contained three parts.

\section{Demographics}

The first part of the questionnaire solicited demographic data about school grade and gender.

\section{Actual experiences of dissection and opinions about what items should} be dissected

The second part required participants to mark in yes/no format if they had examined or touched or dissected some mammalian organs during biology classes, and if they had, which organs (see Table 1). In the same table, they also had to mark in yes/no format which organs they would like to examine or touch or dissect during school laboratory sessions.

Results of actual experiences with dissection of mammalian organs (Cronbach's alpha $=0.612$ ) can be recognised as biased, because of the small number of examined classes, which can influence outcomes because of the habits and practices of the small number of teachers teaching our sample; this does not permit the transfer of findings to the whole population of students.

However, the results of opinions on which mammalian organs should be dissected (Cronbach's alpha $=0.862$ ) can be recognised as representative.

\section{Attitudes toward dissection as a school practice}

The third part was a scale with 12 statements created to explore participants' attitudes toward dissection as a school practice. The answering format was a 5-point Likert scale, as follows: 1 = definitely disagree; 2 = disagree; 3 = neutral; $4=$ agree; 5 = definitely agree. The Cronbach reliability coefficient for the scale is $\mathrm{o.87}$, which can be considered appropriate for further analyses.

\section{Statistical procedures}

The statistical procedures employed were as follows:

a) Descriptive statistics: prior to statistical analysis, variables were checked for normality. The Kolmogorov-Smirnov $\mathrm{Z}$ test (KS test) at the 0.05 significance level was used. Because all variables do not follow normal distribution, nonparametric statistic was preformed (Erceg-Hurn \& Mirosevich, 2008). Due to skewed data frequencies, mode and median are reported. Means and standard deviations are reported only to obtain a 
better impression of data distribution. The reliability of the scales was explored by the calculation of Cronbach's alpha, and by further analysis with the 'alpha if item deleted' procedure in order to foresee possible improvements of the scales. Due to satisfactory alpha levels and to preserve the breadth of the scale, no items were deleted from a pool even if an increase in alpha was predicted.

b) Principal Component Analysis with Direct Oblimin rotation was used to explore the factorial structure of the attitudes toward dissection as a school practice scale because of correlated items. Prior to the analyses, KMO (.912) and Barlett's test (Chi-Square $=2363,8 ; \mathrm{df}=66$; sig $<.001$ ) were performed, with a scale falling into the range in which further analyses are permitted. Principal components with Eigenvectors above 1, and items with loadings above the 0.4 level are reported due to the breath of the reported findings; however, parallel analysis (Flora \& Curran, 2004) was the preferred choice to explore the number of factors to be retained.

c) Correlations were checked as parts of analyses provided by Factorial and Regression procedures. Pearson's correlation coefficients were calculated; coefficients below the 0.05 level (two-tailed) were considered significant.

d) Regression analysis: Linear regression analysis was performed with the enter and case-wise deletion option; variables below the 0.05 level (twotailed) were considered significant.

e) Effect size was used to examine differences in opinions by students' school level (between lower secondary and upper secondary school) and gender. With the next equation: $r=-\frac{Z}{\sqrt{N}}$ was calculated Effect size; where $Z=$ Kolmogorov - Smirnov $Z$ and $\sqrt{N}=$ the square root of the sample size (Field, 2009, p. 550), and in the case of related data output of Wilcoxon's matched pair test.

Microsoft $^{t}$ Excel 2010 was used for data input. The analyses were performed with the SPSS $21^{\circ}$ statistical package according to the procedures suggested by Field (2009).

\section{Results}

\section{Students' dissection and their interest in it regarding school level and gender}

The students had two tasks. The first was to mark if they had examined touched or dissected fresh mammalian organs during biology classes and, if they had, which organs. The second task was to mark whether they would like 
to examine, touch, or dissect fresh mammalian organs and, if so, which organs. A list of seven mammalian organs regularly available to the teachers and the open-ended option 'other' were given (Table 1).

Table 1. Frequency of students, who have examined, touched or dissected mammalian organs and their interest in such practice to be performed in biology classes $(N=483)$

\begin{tabular}{lccccc}
\hline \multirow{2}{*}{ Organ } & \multicolumn{2}{c}{$\begin{array}{l}\text { In biology classes, we have exam- } \\
\text { ined, touched or dissected organs }\end{array}$} & $\begin{array}{c}\text { For better understanding, I would like } \\
\text { to examine, touch, or dissect organs }\end{array}$ & $\begin{array}{c}\text { Difference } \\
\text { (N2 - N1) }\end{array}$ \\
\cline { 2 - 6 } & Frequency (N1) & Percent & Frequency (N2) & Percent & Diff \\
\hline bones & 200 & 41.41 & 310 & 64.18 & 110 \\
eyes & 156 & 32.29 & 300 & 62.11 & 144 \\
hearth & 117 & 24.22 & 341 & 70.60 & 224 \\
livers & 117 & 24.22 & 262 & 54.24 & 145 \\
kidneys & 98 & 20.29 & 270 & 55.90 & 172 \\
brains & 79 & 16.36 & 333 & 68.94 & 254 \\
stomach & 44 & 9.11 & 254 & 52.58 & 210 \\
other & 16 & 3.31 & 28 & 5.79 & 12 \\
\hline
\end{tabular}

From Table 1, we can recognise that bones and eyes are the most commonly dissected mammalian organs in Slovenian schools, while brains and livers were the least commonly dissected. Except for eyes, which are normally discarded in slaughterhouses, all other organs are easily obtainable in local supermarkets for human or animal consumption. However, students' 'wish list' about what should be examined differs significantly from what they actually do in a school in all cases, with heart and brains at the top, and no organ falling below the $50 \%$ margin.

We were not able to find any statistically significant differences on performance and opinions about dissection between genders, except for the field 'other' in the opinion part, where boys are more enthusiastic than girls with their proposals about organs to be added. Statistically significant differences are also present among lower and upper secondary students; however, differences expressed as effect sizes are almost non-existent and small, all falling below $\mathrm{r}<$ .12 levels. Differences in actual dissection between lower and upper secondary schools also exist, but do not exceed small or lower margin of medium levels, with the highest sizes for brains $(r=0.2)$ and bones and livers $(r=0.4)$. 
Table 2. Number of organs that students actually dissected and number of organs they would like to dissect

\begin{tabular}{lcccc}
\hline \multirow{2}{*}{$\begin{array}{l}\text { Number of } \\
\text { organs }\end{array}$} & $\begin{array}{c}\text { In biology classes we have examined, } \\
\text { touched, or dissected organs }\end{array}$ & $\begin{array}{c}\text { For better understanding, I would like to } \\
\text { examine, touch, or dissect organs }\end{array}$ \\
\cline { 2 - 5 } & Frequency & Percent & Frequency & Percent \\
\hline 0 & 111 & 22.98 & 67 & 13.87 \\
1 & 176 & 36.44 & 30 & 6.21 \\
2 & 75 & 15.53 & 32 & 6.63 \\
3 & 46 & 9.52 & 57 & 11.80 \\
4 & 33 & 6.83 & 46 & 9.52 \\
5 & 25 & 5.18 & 45 & 9.32 \\
6 & 13 & 2.69 & 32 & 6.63 \\
7 & 4 & 0.83 & 160 & 33.13 \\
8 & 0 & 0.00 & 14 & 2.89 \\
\hline Total & 483 & 100.0 & 483 & 100.0 \\
\hline
\end{tabular}

From Table 2, we can recognise that about $23 \%$ of students from our sample had never examined, touched or dissected animal organs as laboratory work, and less than $10 \%$ had experiences with more than five organs. The statistical difference between elementary and secondary schools in the performance of actual dissection is insignificant $(\mathrm{U}=27958 ; \mathrm{p}=.75 ; \mathrm{r}=.01)$.

However, only $13.9 \%$ of students declared that they would not like to examine, touch or dissect organs, and more than half (51.9\%) declared that they would like to examine, touch or dissect more than five different organs. Prior to the study, we thought that practice would predict desired practice in negative or positive ways, but correlations between the sum of actually dissected organs from the list and organs that students would like to dissect practically do not exist $(\mathrm{r}=-0.06, \mathrm{p}=0.20)$. Differences between genders are statistically insignificant $(\mathrm{U}=27248.5 ; \mathrm{p}=.38 ; \mathrm{r}=.04)$. Slightly larger, but marginally significant at $\mathrm{p}<.01$ levels, are differences in the desire to dissect between elementary and secondary school students $(U=25526 ; \mathrm{p}=.05 ; \mathrm{r}=.09)$ : elementary school students show slightly more enthusiasm for such activities. 
Table 3. Differences between the number of mammalian organs students actually dissected and the number of organs they would (dis)like to dissect

\begin{tabular}{lcc}
\hline Difference & Frequency & Percent \\
\hline-8 & 2 & 0.41 \\
-7 & 48 & 9.94 \\
-6 & 64 & 13.25 \\
-5 & 50 & 10.35 \\
-4 & 53 & 10.97 \\
-3 & 47 & 9.73 \\
-2 & 47 & 9.73 \\
-1 & 33 & 6.83 \\
0 & 61 & 12.63 \\
1 & 26 & 5.38 \\
2 & 19 & 3.93 \\
3 & 14 & 2.89 \\
4 & 8 & 1.66 \\
5 & 10 & 2.07 \\
7 & 1 & 0.21 \\
\hline Total & 483 & 100.0 \\
\hline
\end{tabular}

Differences for individual students between what was actually dissected and what is on their wish list shows that only $12.6 \%$ of students (difference is o) are satisfied with what happens in their biology classes. The negative values show that most of them (71.2\%) would like to dissect more organs than they actually did, and only about $16.2 \%$ would like to dissect fewer. Differences between genders are not statistically significant $(\mathrm{U}=26945.5 ; \mathrm{p}=.28 ; \mathrm{r}=.05)$, and between elementary and secondary schools as well $(\mathrm{U}=25889 ; \mathrm{p}=.09 ; \mathrm{r}=.08)$ in favour of elementary schools.

\section{Opinions about teaching and learning practices in which fresh mammalian materials are used}

Results of opinions provided by elementary and secondary school students are provided in Table 4; differences between genders and school levels, calculated by Mann Whitney test, ranks, $\mathrm{p}$-values and effect sizes are provided in the Appendix. 
Table 4. Opinions about teaching and learning practices in which fresh mammalian materials are used

\begin{tabular}{|c|c|c|c|c|c|c|c|c|c|c|c|c|c|c|}
\hline No & Statement & $\mathbf{N}$ & $\mathrm{F} 1$ & $\mathrm{~F} 2$ & F3 & $\mathrm{F} 4$ & F5 & M & SD & $\mathrm{Me}$ & Mod & PC1 & PC2 & PC3 \\
\hline 14 & $\begin{array}{l}\text { Work with fresh materials should } \\
\text { be included in lessons about the } \\
\text { human body. }\end{array}$ & 482 & $\begin{array}{c}55 \\
11.42\end{array}$ & $\begin{array}{c}53 \\
11.00\end{array}$ & $\begin{array}{c}109 \\
22.62\end{array}$ & $\begin{array}{c}123 \\
25.48\end{array}$ & $\begin{array}{c}142 \\
29.48\end{array}$ & 3.51 & 1.32 & 4 & 5 & .88 & -.08 & .12 \\
\hline 9 & $\begin{array}{l}\text { I would like to work with fresh } \\
\text { materials more often. }\end{array}$ & 482 & $\begin{array}{c}60 \\
12.45\end{array}$ & $\begin{array}{c}58 \\
12.03\end{array}$ & $\begin{array}{c}96 \\
19.92\end{array}$ & $\begin{array}{c}105 \\
21.78\end{array}$ & $\begin{array}{c}163 \\
33.82\end{array}$ & 3.52 & 1.39 & 4 & 5 & .85 & .00 & -.00 \\
\hline 3 & $\begin{array}{l}\text { When we work with fresh mam- } \\
\text { malian organs (brains, eyes, etc.) } \\
\text { in biology lessons, it motivates me } \\
\text { more for classroom cooperation } \\
\text { and learning. }\end{array}$ & 482 & $\begin{array}{c}65 \\
13.49\end{array}$ & $\begin{array}{c}48 \\
9.96\end{array}$ & $\begin{array}{c}85 \\
17.63\end{array}$ & $\begin{array}{c}101 \\
20.95\end{array}$ & $\begin{array}{c}183 \\
37.97\end{array}$ & 3.60 & 1.42 & 4 & 5 & .85 & -.02 & .03 \\
\hline 1 & $\begin{array}{l}\text { During anatomy and physiology } \\
\text { lessons about the human body, I } \\
\text { would like to examine, touch or } \\
\text { dissect mammalian organs. }\end{array}$ & 481 & $\begin{array}{c}49 \\
10.19\end{array}$ & $\begin{array}{c}45 \\
9.36\end{array}$ & $\begin{array}{c}111 \\
23.08\end{array}$ & $\begin{array}{c}98 \\
20.36\end{array}$ & $\begin{array}{l}178 \\
37.01\end{array}$ & 3.65 & 1.33 & 4 & 5 & .83 & -.03 & .14 \\
\hline 15 & $\begin{array}{l}\text { Because of work with fresh ma- } \\
\text { terials, I would more easily make } \\
\text { a decision about a profession in } \\
\text { medicine. }\end{array}$ & 482 & $\begin{array}{c}70 \\
14.52\end{array}$ & $\begin{array}{c}64 \\
13.28\end{array}$ & $\begin{array}{c}118 \\
24.48\end{array}$ & $\begin{array}{c}86 \\
17.84\end{array}$ & $\begin{array}{c}144 \\
29.88\end{array}$ & 3.35 & 1.40 & 3 & 5 & .68 & -.09 & .24 \\
\hline 4 & $\begin{array}{l}\text { I do not like to work with fresh } \\
\text { materials. }\end{array}$ & 483 & $\begin{array}{c}176 \\
36.44\end{array}$ & $\begin{array}{c}104 \\
21.53\end{array}$ & $\begin{array}{c}102 \\
21.12\end{array}$ & $\begin{array}{c}41 \\
8.49\end{array}$ & $\begin{array}{c}60 \\
12.42\end{array}$ & 2.39 & 1.37 & $\begin{array}{c}2 \\
(4)\end{array}$ & $\begin{array}{c}1 \\
(5)\end{array}$ & .68 & .18 & -.22 \\
\hline 10 & $\begin{array}{l}\text { I prefer that a teacher show us a } \\
\text { model or a picture of an organ } \\
\text { than showing us a fresh one. }\end{array}$ & 483 & $\begin{array}{c}108 \\
22.36\end{array}$ & $\begin{array}{c}124 \\
25.67\end{array}$ & $\begin{array}{c}119 \\
24.64\end{array}$ & $\begin{array}{c}55 \\
11.39\end{array}$ & $\begin{array}{c}77 \\
15.94\end{array}$ & 2.73 & 1.35 & $\begin{array}{c}3 \\
(3)\end{array}$ & $\begin{array}{c}2 \\
(4)\end{array}$ & .64 & .14 & -.37 \\
\hline 5 & $\begin{array}{l}\text { When I see fresh mammalian } \\
\text { organs, I feel sick. }\end{array}$ & 482 & $\begin{array}{c}178 \\
36.93\end{array}$ & $\begin{array}{c}105 \\
21.78\end{array}$ & $\begin{array}{c}88 \\
18.26\end{array}$ & $\begin{array}{c}48 \\
9.96\end{array}$ & $\begin{array}{c}63 \\
13.07\end{array}$ & 2.40 & 1.40 & $\begin{array}{c}2 \\
(4)\end{array}$ & $\begin{array}{c}1 \\
(5)\end{array}$ & .42 & .33 & -.40 \\
\hline 6 & $\begin{array}{l}\text { I cannot recognise a difference } \\
\text { between learning from fresh ma- } \\
\text { terial or plastic model of brains. }\end{array}$ & 483 & $\begin{array}{c}170 \\
35.20\end{array}$ & $\begin{array}{c}118 \\
24.43\end{array}$ & $\begin{array}{c}108 \\
22.36\end{array}$ & $\begin{array}{c}43 \\
8.90\end{array}$ & $\begin{array}{l}44 \\
9.11\end{array}$ & 2.32 & 1.29 & $\begin{array}{c}2 \\
(4)\end{array}$ & $\begin{array}{c}1 \\
(5)\end{array}$ & .42 & .05 & -.10 \\
\hline 7 & $\begin{array}{l}\text { I do not like to learn about the } \\
\text { human body. }\end{array}$ & 482 & $\begin{array}{c}219 \\
45.44\end{array}$ & $\begin{array}{c}114 \\
23.65\end{array}$ & $\begin{array}{c}88 \\
18.26\end{array}$ & $\begin{array}{c}38 \\
7.88\end{array}$ & $\begin{array}{c}23 \\
4.77\end{array}$ & 2.03 & 1.18 & $\begin{array}{c}2 \\
(4)\end{array}$ & $\begin{array}{c}1 \\
(5)\end{array}$ & .09 & .77 & .11 \\
\hline 12 & $\begin{array}{l}\text { Processes inside our body that } \\
\text { we cannot see are not important, } \\
\text { so it is unnecessary to burden us } \\
\text { with them. }\end{array}$ & 482 & $\begin{array}{c}250 \\
51.87\end{array}$ & $\begin{array}{c}94 \\
19.50\end{array}$ & $\begin{array}{c}93 \\
19.29\end{array}$ & $\begin{array}{c}22 \\
4.56\end{array}$ & $\begin{array}{c}23 \\
4.78\end{array}$ & 1.91 & 1.15 & $\begin{array}{c}1 \\
(5)\end{array}$ & $\begin{array}{c}1 \\
(5)\end{array}$ & -.13 & .87 & .07 \\
\hline 8 & $\begin{array}{l}\text { I like themes that are connected } \\
\text { to everyday life. }\end{array}$ & 483 & $\begin{array}{c}17 \\
3.52\end{array}$ & $\begin{array}{c}15 \\
3.11\end{array}$ & $\begin{array}{c}80 \\
16.56\end{array}$ & $\begin{array}{c}149 \\
30.85\end{array}$ & $\begin{array}{c}222 \\
45.96\end{array}$ & 4.13 & 1.03 & 4 & 5 & .17 & .25 & .83 \\
\hline & Cronbach's alpha & & & & & & & & & & & .89 & .57 & NA \\
\hline & Variance explained & & & & & & & & & & & 43.0 & 10.3 & 9.60 \\
\hline & Eigenvalue & & & & & & & & & & & 5.17 & 1.23 & 1.15 \\
\hline
\end{tabular}

Note: Results are sorted by decreasing values of Principal Components (PC1-PC3). Percentages are given below frequencies (F1-F5). Values in Values in brackets in Median (Me) and Modus (Mod) Columns are reverse coded.

Three principal components (Table 4) were extracted using eigenvalue > 1 criteria, but only one factor is retained. From the factor itself and frequencies of answers (items) composing it can be revealed that most of the students are 
supportive toward the inclusion of fresh mammalian organs in their instructions. They recognise learning about human body and processes inside it as important and like themes connected to everyday life. Differences between genders (See Appendix), even if statistically significant, are expressed as effect size values, small, and exceed the .2 level in only one item, showing a greater interest of girls toward processes inside their body. Similarly, all differences in opinions between elementary and secondary school students fall below .15 margins. Small effect size values allow us to treat the whole sample as one group in our analyses.

\section{Discussion}

Dissection of mammalian organs is a preferred activity for the largest number of students, regardless of gender or school levels. These findings are in line with previous knowledge that practical and active work is what students missed the most in Slovenian biology education (Šorgo \& Špernjak, 2007). However, many students do not have this opportunity, because a number of teachers rely on presentations, even if laboratory alternatives are available (Šorgo, Usak, Aydogdu, Keles \& Ambrozic-Dolinsek, 2011); active methods, laboratory work included, is recommended by syllabi of science subjects (Šorgo \& Špernjak, 2012). From the study, we cannot make definite conclusions about the reasons of teachers for the exclusion of dissections from their laboratory practices. Implicitly, for a number of teachers, the reasons are most probably a combination of overloaded curricula, preferred explanatory style of instructions, commodity, costs of fresh materials, and the safety of avoiding critiques or pressures from the minority of parents and opinion makers who are opponents of such practices. A study answering these questions is necessary.

From the presented results (Tables 1, 2, 3), we can conclude that only a minority of students (less than $15 \%$ ) would potentially like to opt-out from dissection practice or perform it in an alternative way; most of the students would like to dissect more frequently. Statistical differences between genders and school levels are insignificant, so we can differentiate between them only on the basis of their abilities. This finding can be used as an incentive toward the introduction of more interesting and active teaching practices, dissection included, often absent from Slovenian science education (Ploj Virtič \& Šorgo, 2016; Šorgo \& Kocijančič, 2011; Šorgo \& Špernjak, 2012).

Given that science is not one of the most popular subjects for a majority of students, the exclusion of dissection from laboratory work would sacrifice valuable teaching practice that can make it more interesting and appealing to them. Although we respect most of the arguments against dissection of animals 
in a school classroom, we would not recommend discarding dissection, but would allow an opt-out scheme for the minority of them who would not like to perform or attend dissection, allowing them to fill missing knowledge gaps with alternative methods, such as virtual dissection, or learning from charts.

We do not support the killing of animals in elementary and secondary schools solely for the purpose of dissection. However, we strongly support a practice in which animals or their parts to be used as human or animal food are to be presented in a classroom to students as 'homes of life'. In such a way, arguments regarding the ethics of school dissection can be largely weakened on the basis of arguments that:

a) no animal was sacrificed for the purpose of dissection;

b) they have been slaughtered by professionals according to the existing standards for human consumption;

c) that the presentation of animal organs to the students can not present a greater stress than that of walking through the meat department in supermarkets;

d) that stress from dissection cannot exceed that experienced by home meat preparation for consumption;

e) and last and not least that no part of dissected organs will be discarded, but used to feed other animals, such as lizards, frogs and fish in school aquaria and terraria, or domestic animals, such as dogs and cats.

Dissection as a teaching practice can raise interest in biology, competing with the falling interest in science worldwide among adolescents. The results from our study on attitudes (See Table 4) are similar to findings that dissection is a preferred method of anatomy laboratories at college levels (Lombardi, Hicks, Thompson \& Marbach-Ad, 2014). Osenkowski, Green, Tjaden and Cunniff (2015) also reports students' great interest in dissection and that this the reason that educators still use it, although they would like to exchange dissection with alternatives. According to Lombardi et al. (2014), plastic models may be more effective than organ dissections or virtual dissections for teaching heart anatomy and physiology content, but organ dissections may have the highest perceived practical value and may be superior for improving students' attitudes toward science. In classrooms, a variety of hands-on (including dissection) and model-assisted activities should be used, as this may accommodate students of varied learning styles, and different activities are best suited to achieving different goals. Holstermann et al. (2009) claimed that topics that relate to aspects of human biology are of interest to students, which is confirmed by this study: students like to learn about anatomy and physiology of 
the human body, which is connected to everyday life. Holstermann et al. (2009) also investigated students' disgust and interest in dissection; the results show that dissection has a high potential to influence students' intrinsic motivation positively if the students do not feel disgust. This empirical evidence might be an important argument to justify - and improve - dissection in biology classes.

Differences between genders are present in our study, but are, according to calculated effect sizes, small or even non-existent, and cannot affect teaching. Some studies in the effects of dissection-room experiences in medical schools have also found no gender differences of the impact of dissection (Bernhardt, Rothkötter \& Kasten, 2012), while several others have reported higher levels of stress among women than men (Bernhardt et al., 2012; Dempster, Black, McCorry \& Wilson, 2006). Bernhardt et al. (2012) thought that this may have been due to women being more prepared than men are to admit and divulge their own emotional reactions.

\section{Conclusions}

Based on our results, we can make some conclusions and recommendations to improve biology instruction, to make it more interesting and more effective.

Even if there are many studies arguing that knowledge on anatomy and physiology can be achieved by virtual methods, or using $3 \mathrm{D}$ models, we can argue that a number of studies shows that combinations of hands-on models, and virtual activities should be the preferred choice. Dissection of organs is important for several reasons: students can make a connection between theory and practice; they can feel the structures of organs, observe organs in real size and real colour; observe the inner structures of organs like cardiac valves in the heart or the whiteness and greyness of brain, they can make experiments with the eye lens and observe retina, determine the significance of the cornea strength, determine the flexibility and hardiness of bones, and observe the stomach structure and kidneys. According to Mayer (2007), dissection contributes to more adequate epistemological beliefs. It is also a scientific hands-on activity that develops students' manual skills.

As a final conclusion, we can advise teachers, contributors, and authors of the Slovenian biology syllabi (curricula) that even if dissection is rare in Slovenian biology classes, and some ethical concerns on dissection may exist, this practice should be encouraged. Because of students' interest, and to provide students with the best alternatives toward study of 'homes of their lives', we should encourage dissection together with models and computer simulations 


\section{to make the learning process more effective and interesting. For those who do not wish to participate in dissection, opt-out option should be provided.}

\section{References}

A guide to the international biology Olympiad, Edition 27.0. IBO Coordinating Centre, Prague July 2015. Retrieved 18. 6. 2016 from http://www.ibo-info.org/pdf/IBO-Guide.pdf.

Akpan, J. P., \& Andre, T. (2000). Using a computer simulation before dissection to help students learn anatomy. Journal of Computers in Mathematics and Science Teaching, 19(3), 297-313.

Apkan, J. P. (2002). Which comes first: Computer simulation of dissection or a traditional laboratory practical method of dissection. Electronic Journal of Science Education, 6(4). Retrieved 15. 6. 2016 from http://ejse.southwestern.edu/article/view/7686/5453.

Balcombe, J. (2000). The use of animals in higher education: Problems, alternatives, and recommendations. Washington, DC: The Humane Society Press.

Bernhardt, V., Rothkötter, H. J., \& Kasten E. (2012). Psychological Stress In First Year Medical Students In Response To The Dissection Of A Human Corpse. GMS Zeitschrift fur Medizinische Ausbildung, 29(1), 1-17. doi: 10.3205/zmaooo782

Bishop, L. J., \& Nolen, A. L. (2001). Animals in research and education: Ethical issues. Kennedy Institute of Ethics Journal, 11(1), 91-112. doi: 10.1353/ken.2001.0006

Cottam, W. W. (1999). Adequacy of medical school gross anatomy education as perceived by certain postgraduate residency programs and anatomy course directors. Clinical Anatomy, 12(1), 55-65. doi: 10.1002/(SICI)1098-2353

Cunningham, P. F. (2000). Animals in psychology education and student choice. Society \& Animals, $8(2), 191-212$.

De Villiers, R., \& Monk, M. (2005). The first cut is the deepest: Reflections on the state of animal dissection in biology education. Journal of Curriculum Studies, 37(5), 583-60o. doi: $10.1080 / 00220270500041523$

Demirhan, E. (2014). Miracle or Cruelty? The Sophomore Prospective Science Teachers' Perspective of Chicken Embryonic Development. Procedia-Social and Behavioral Sciences, 152, 575-581.

Dempster, M., Black A., McCorry N., \& Wilson D. (2006). Appraisal and consequences of cadaver dissection. Med Educ Onlin. 11, 16.

Entrich, H. (1996). Präparationen. Basisartikel [Dissections. Introduction to the special issue].

Unterricht Biologie, 20, 4-13.

Erceg-Hurn, D. M., \& Mirosevich V. M., (2008). Modern robust statistical methods: an easy way to maximize the accuracy and power of your research. The American psychologist, 63(7), 591-601. doi: 10.1037/0003-066X.63.7.591.

Fancovicova, J., \& Prokop, P. (2014). The effects of 3 D plastic models of animals and cadaveric dissection on students' perceptions of the internal organs of animals. Journal of Baltic Science Education. 13(4), 767-775. 
Field, A. (2009). Discovering statistics using SPSS ( $3^{\text {rd }}$ edition). London: Sage Publications. Flora, D. B., \& Curran, P. J. (2004). An empirical evaluation of alternative methods of estimation for confirmatory factor analysis with ordinal data. Psychological Methods, 9(4), 466-491.

Fredieu, J. R., Kerbo, J., Herron, M., Klatte, R., \& Cooke, M. (2015). Anatomical Models: a Digital Revolution. Medical Science Educator, 25(2), 183-194.

Holstermann, N., Grube, D., \& Bögeholz, S. (2009). The influence of emotion on students' performance in dissection exercises. Journal of Biological Education, 43 (4), 164-168. doi: 10.1080/00219266.2009.9656177

Hug, B. (2008). Re-examining the practice of dissection: What does it teach? Journal of Curriculum Studies, 40(1), 91-105. doi: 10.1080/00220270701484746

ISCED: International Standard Classification of Education, (2011). Retrieved 28. 8. 2015 from http:// www.uis.unesco.org/Education/Pages/international-standard-classification-of-education.aspx. Jukes, N., \& Chiuia, M. (2003). From guinea pig to computer mouse: Alternative methods for a progressive, humane education ( $2^{\text {nd }}$ edition). Leicester: InterNICHE.

Kerby, J., Shukur, Z. N. \& Shalhoub, J. (2011). The relationships between learning outcomes and methods of teaching anatomy as perceived by medical students. Clinical Anatomy, 24(4), 489-497. doi: 10.1002/ca.21059

Lalley, J. P., Piotrowski, P. S., Battaglia, B., Brophy, K., \& Chugh, K. (2010). A comparison of V-Frog@ to physical frog dissection. International Journal of Environmental and Science Education, 5(2), 189-200. Lombardi, S. A., Hicks, R. E., Thompson, K. V., \& Marbach-Ad, G. (2014). Are all hands-on activities equally effective? Effect of using plastic models, organ dissections, and virtual dissections on student learning and perceptions. Advances in Physiology Education. 38(1), 80-86. doi: 10.1152/ advan.00154.2012

Macchi, V., Porzionato, A., Stecco, C., \& Caro, R. (2014). Evolution of the anatomical theatre in Padova. Anatomical sciences education, 7(6), 487-493.

Maloney, R. (2005). Exploring virtual fetal pig dissection as a learning tool for female high school biology students. Educational Research and Evaluation, 11(6), 591-603. doi: $10.1080 / 13803610500264823$

Marr, R. K. (2001). Dissection: Where and when is it appropriate in the teaching laboratory? Journal of Applied Animal Welfare Science, 4(2), 139-141. doi: 10.1207/S15327604JAWSo402_7 Mattheis, A., Ingram, D., Jensen, M. S., \& Jackson. J. (2015). Examining high school anatomy and physiology teacher experience in a cadaver dissection laboratory and impacts on practice. International Journal of Science and Mathematics Education. 13(3), 535-559. doi: 10.1007/s10763-0139507-8

Mayer, J. (2007). Erkenntnisgewinnung als wissenschaftliches Problemlösen [Gaining knowledge as scientific reasoning]. In D. Krüger \& H. Vogt (Eds.), Theorien in der biologiedidaktischen Forschung [Theories in biologiedidactic research] (pp. 177-186). Berlin: Springer. McMenamin, P. G., Quayle, M. R., McHenry, C. R., \& Adams, J. W. (2014). The production of anatomical teaching resources using three-dimensional $(3 \mathrm{D})$ printing technology. Anatomical 
sciences education, $7(6)$, 479-486.

National Science Teachers Association [NSTA] (2005). Responsible use of live animals and dissection in the science classroom. NSTA Position Statement. Retrieved 3. 11. 2015 from http://www.nsta.org/ docs/PositionStatement_LiveAnimalsAndDissection.pdf.

Oakley, J. (2009). Under the knife: Animal dissection as a contested school science activity. Journal for Activist Science and Technology Education, 1(2), 59-67.

Oakley, J. (2011). Science teachers and the dissection debate: Perspectives on animal dissection and alternatives. International Journal of Environmental \& Science Education, 7(2), 253-267.

Osenkowski, P., Green, C., Tjaden, A., \& Cunniff, P. (2015). Evaluation of Educator \& Student Use of \& Attitudes toward Dissection \& Dissection Alternatives. The American Biology Teacher, 77 (5), $340-346$.

Peat, M., \& Taylor, C. (2005). Virtual biology: how well can it replace authentic activities?. International Journal of Innovation in Science and Mathematics Education (formerly CAL-laborate International), 13(1), 21-24.

Richardson, D. (2011). Is virtual reality a useful tool in the teaching of physiology? Advances in Physiology Education, 35, 117-119. doi: 10.1152/advan.0ooo2.2011

Saltarelli, A. J., Roseth, C. J., \& Saltarelli, W. A. (2014). Human cadavers Vs. multimedia simulation: A study of student learning in anatomy. Anatomical sciences education, 7(5), 331-339.

Sapontzis, S. F. (1995). We should not allow dissection of animals. Journal of Agricultural and Environmental Ethics, 8(2), 181-189. doi: 10.1007/BFo2251883

Smetana, L. K., \& Bell, R. L. (2012). Computer simulations to support science instruction and learning: A critical review of the literature. International Journal of Science Education, 34(9), 1337-1370.

Šorgo, A., \& Kocijančič, S. (2011). Presentation of laboratory sessions for science subjects in Slovenian upper secondary schools. Journal of Baltic Science Education, 10(2), 98-113.

Šorgo, A., Usak, M., Aydogdu, M., Keles, O., \& Ambrozic-Dolinsek, J. (2011). Biology teaching in upper secondary schools: comparative study between Slovenia and Turkey. Energy education Science and Technology Part B: Social and Educational Studies, 3(3), 305-314.

Šorgo, A., \& Špernjak, A. (2007). Profesorice bi morale bit zgoraj brez ali kaj spremeniti v pouku biologije [Professors should be topless or what to change in biology class]. Vzgoja in izobraževanje, $38(5), 37-40$.

Šorgo, A., \& Špernjak, A. (2012). Practical work in Biology, Chemistry and Physics at lower secondary and general upper secondary schools in Slovenia. Eurasia Journal of Mathematics, Science \& Technology Education, 8(1), 11-19.

Virtič, M. P., \& Šorgo, A. (2016). Can we expect to recruit future engineers among students who have never repaired a toy?. Eurasia Journal of Mathematics, Science \& Technology Education, 12(2), $249-266$.

Winkelmann, A. (2007). Anatomical dissection as a teaching method in medical school: A review of the evidence. Medical Education, 41(1), 15-22. doi: 10.1111/j.1365-2929.2006.02625.x 


\section{Biographical note}

Andreja Špernjak, PhD, is an assistant for Didactics of Biology at Faculty of Natural Sciences and Mathematics, University of Maribor. She works with students from lower secondary school to students at university. Her main research field is didactics of biology.

ANDrej Šorgo, PhD, is an Associate Professor of Biology Didactics at the Faculty of Natural Sciences and Mathematics, and a part time researcher at the Faculty of Electrical Engineering and Computer Science, University of Maribor. He has Masters and PhD degrees in Biology from the University of Ljubljana. He has published textbooks, and research articles and presented his work at number of conferences. He has over 20 years of experience as a secondary and higher vocational school teacher. He has won an award for being 'The most innovative secondary school teacher'. 


\section{Appendix}

Differences between genders and school levels, calculated by Mann Whitney test, ranks, p-values and effect sizes.

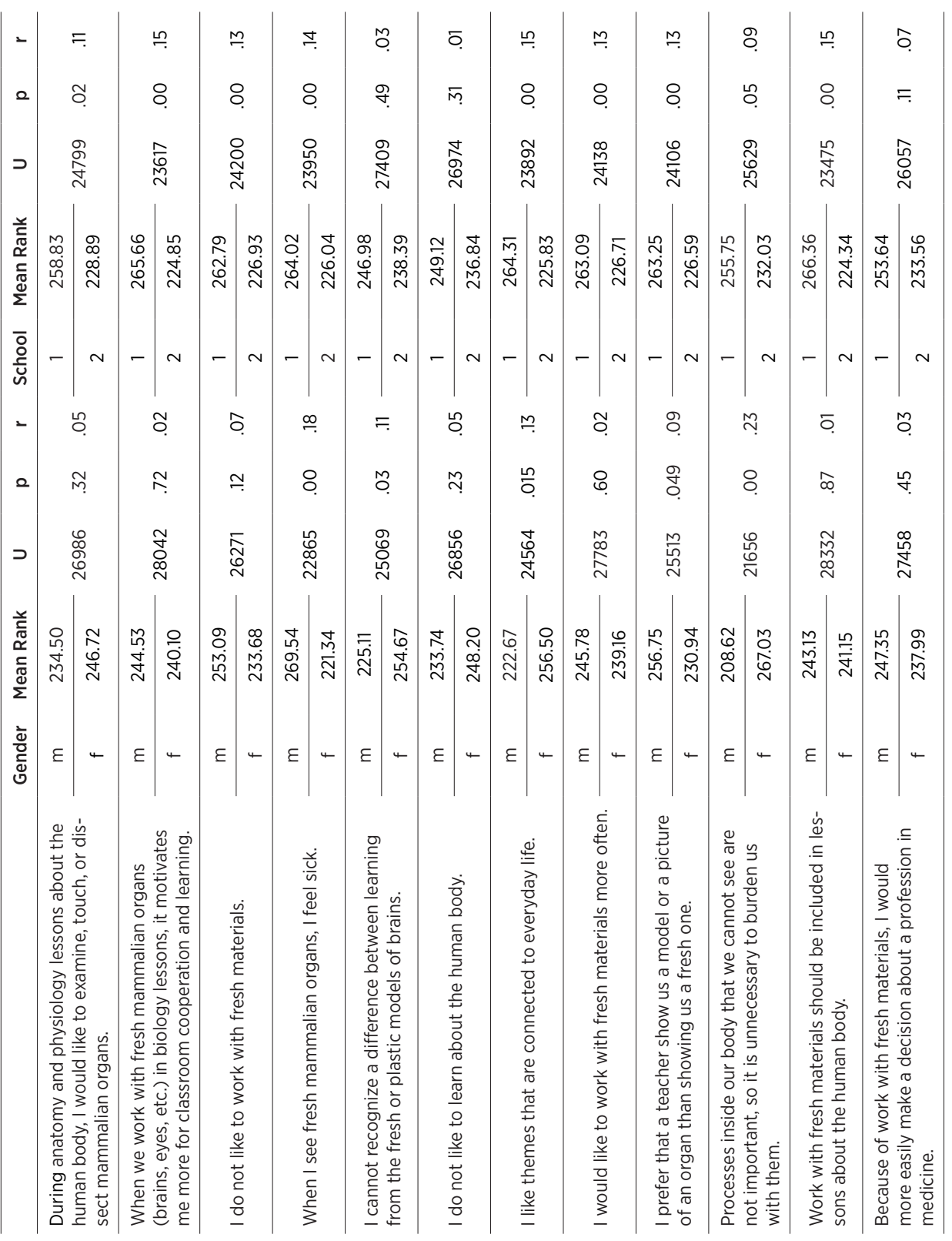

Note: In all items, except in item $1(\mathrm{~N}=482)$ total number of responses is 483 . Number of males is 207 (206), and females 276; number of elementary school students is 203 , and secondary school students 280 (279). 